\title{
A survey of mastitis pathogens including antimicrobial susceptibility in southeastern Australian dairy herds
}

\author{
R. Dyson, ${ }^{1} \odot$ N. Charman, ${ }^{2} \oplus$ A. Hodge, ${ }^{2} \odot$ S. M. Rowe, ${ }^{3} \odot$ and L. F. Taylor ${ }^{2 *} \odot$ \\ ${ }^{1}$ Dairy Focus, 181 Wharparilla Drive, Echuca, Victoria, 3564, Australia \\ ${ }^{2}$ Zoetis Australia, 5 Rider Blvd, Rhodes, New South Wales, 2138, Australia \\ ${ }^{3}$ Faculty of Science, Sydney School of Veterinary Science, The University of Sydney, Camden, New South Wales 2570, Australia
}

\begin{abstract}
The objectives for this study were to (1) describe the pathogen profile in quarters from cows with clinical mastitis and in cows with subclinical mastitis in southeastern Australia; and (2) describe antimicrobial susceptibility among isolated pathogens. As a secondary objective, we aimed to compare antimicrobial resistance prevalence in pathogens isolated from clinical and subclinical mastitis samples. A convenience sample of dairy herds $(\mathrm{n}=65)$ from 4 regions in southeastern Australia (Gippsland, Northern Victoria, Tasmania, Western Victoria) were invited to submit milk samples from cows with clinical and subclinical mastitis over a 14-mo period (January 2011 to March 2012). Farmers were instructed to collect aseptic quarter milk samples from the first 10 cases of clinical mastitis for each month of the study. In addition, farmers submitted composite milk samples from cows with subclinical mastitis at 1 or 2 sampling occasions during the study period. Aerobic culture and biochemical tests were used to identify isolates. Isolates were classified as susceptible, intermediate, or resistant to a panel of antimicrobial agents based on the zone of growth inhibition around antimicrobial-impregnated disks, with antimicrobial resistance (AMR) classified as nonsusceptibility by combining intermediate and resistant groups into a single category. Generalized linear mixed models were used to compare the prevalence of AMR between clinical and subclinical mastitis isolates. For clinical mastitis samples $(\mathrm{n}=3,044), 472$ samples $(15.5 \%)$ were excluded for contamination. Of the remaining samples $(\mathrm{n}=2,572)$, the most common results were Streptococcus uberis (39.2\%), no growth (27.5\%), Staphylococcus aureus (10.6\%), Escherichia coli (8.4\%), and Streptococcus dysgalactiae (6.4\%). For subclinical mastitis samples $(\mathrm{n}=1,072), 425(39.6 \%)$
\end{abstract}

Received July 1, 2021.

Accepted October 23, 2021.

*Corresponding author: lee.f.taylor@zoetis.com were excluded due to contamination. Of the remaining samples $(\mathrm{n}=647)$, the most common results were no growth (29.1\%), Staph. aureus (29.1\%), and Strep. uberis (21.6\%). The prevalence of AMR among common isolates was low for the majority of antimicrobial agents. Exploratory analysis found that the probability of Staph. aureus demonstrating resistance to penicillin was 5.16 times higher (95\% confidence interval: 1.68, 15.88) in subclinical isolates relative to clinical Staph. aureus isolates. A similar association was observed for amoxicillin with subclinical Staph. aureus isolates being 4.70 times (95\% confidence interval: 1.49, 14.75) more likely to be resistant than clinical Staph. aureus isolates. We concluded that the most common bacteria causing clinical mastitis in dairy herds in Australia is likely to be Strep. uberis, whereas Staph. aureus is likely to be the most common cause of subclinical mastitis. Despite decades of antimicrobial use to control these organisms, AMR appears to be uncommon.

Key words: mastitis, antimicrobial resistance, Streptococcus uberis, Staphylococcus aureus

\section{INTRODUCTION}

Mastitis is consistently ranked as one of the most significant diseases affecting dairy cattle worldwide (Halasa et al., 2007; Rollin et al., 2015) due to its effects on health, welfare, and productivity. It is estimated that udder health issues, of which mastitis is a major component, cost the Australian dairy industry $\mathrm{A} \$ 150 \mathrm{M}$ (US $\$ 110 \mathrm{M}$ ) per year (Brightling et al., 2018), and each individual case of clinical mastitis costs $\mathrm{A} \$ 360$ (US $\$ 260$; S. Bullen, Dairy Australia, Melbourne, Australia, personal communication).

Understanding the pathogen profile for mastitis is critical to management. For example, understanding the industry and farm-level pathogen profiles for clinical and subclinical mastitis can inform treatment protocols and identify interventions to prevent new cases through the strategic targeting of likely reservoirs of infection. There have been no large surveys of mastitis etiol- 
ogy in Australia, especially in southeastern Australia, where a large proportion of the Australian dairy herd is located. Small surveys have described the prevalence of clinical mastitis pathogens in dairy farming regions in Australia over the past $40 \mathrm{yr}$, including herds from Queensland (Daniel et al., 1982), the Gippsland region of Victoria (Watson et al., 1996; Gunn et al., 1999), and New South Wales (Shum et al., 2009). The findings from these studies indicate that the etiology of clinical mastitis has changed over time, with a shift from pathogens that commonly cause contagious mastitis (i.e., Staphylococcus aureus and Streptococcus agalactiae) toward pathogens that are commonly found in the environment of cows, namely Streptococcus uberis. This is consistent with global trends in bovine mastitis in developed countries (Ruegg, 2017); however, the mix of environmental pathogens identified in previous Australian studies has varied between studies (Gunn et al., 1999; Shum et al., 2009).

Given the reliance on antimicrobials for the treatment and control of mastitis and the growing concern over the risk of antimicrobial resistance (AMR) and its effect on public health, surveillance for AMR is a recommendation under the Office International des Epizooties (OIE) strategy for combating AMR (WHOOIE, 2016). The Australian dairy industry has implemented an antimicrobial stewardship program based on these guidelines (Dairy Australia, 2021). Surveillance for AMR is an important component of this strategy. Only one of the aforementioned Australian surveys, from 1982, included assessment of the susceptibility of cultured pathogens to common antimicrobial agents used for the treatment and control of mastitis (Daniel et al., 1982). In this study, Staph. aureus accounted for $58 \%$ of isolates, and Strep. agalactiae was the next most common pathogen, which was isolated from $19 \%$ of samples. Also in this study, $45 \%$ of Staph. aureus isolates were classified as resistant to penicillin, but no Strep. agalactiae isolates were resistant to penicillin. A more recent Australian study found no evidence of methicillin resistance among 203 mastitis-associated Staph. aureus isolates (Worthing et al., 2018). This is reassuring because Staph. aureus remains a significant mastitis pathogen in Australian dairy herds.

A limitation of this Australian dairy-derived Staph. aureus study was that it did not investigate other mastitis pathogens or other antimicrobial agents. Therefore, baseline studies of AMR prevalence among a broad spectrum of clinical and subclinical mastitis pathogens in Australian herds are required for ongoing monitoring of AMR among mastitis pathogens. In addition, describing pathogen profiles at the herd and industry levels for clinical and subclinical mastitis will provide an insight into likely risk factors and inform current and future treatment protocols. For example, describing the proportion of clinical mastitis cases associated with gram-positive pathogens could be used to identify the cost-effectiveness of culture-guided, selective therapy for clinical mastitis under Australian conditions (Down et al., 2017; McDougall et al., 2018).

The objectives for this study were to (1) describe pathogen profiles in quarters from cows with clinical mastitis and in cows with subclinical mastitis in dairy farming regions of southeastern Australia; and (2) describe antimicrobial susceptibility among isolated pathogens. As a secondary objective, we aimed to compare AMR prevalence in pathogens isolated from clinical and subclinical mastitis samples.

\section{MATERIALS AND METHODS}

The Strengthening the Reporting of Observational Studies in Epidemiology - Veterinary Extension (STROBE-Vet) statement guidelines were followed in the reporting of this study (Sargeant et al., 2016). A cross-sectional study of mastitis etiology in southeastern Australian dairy cows was conducted between January 2011 and March 2012. This study was conducted under animal ethics approval authorized by the CSL Limited Pfizer Australia Animal Ethics Committee on October 11, 2010 (approval number 8,540). No sample size calculations were performed before the study.

\section{Recruitment of Herds}

A convenience sample of 65 herds from 3 dairy farming regions in Victoria (Western Victoria, Northern Victoria, and Gippsland) and Tasmania was enrolled with the assistance of 13 participating veterinary clinics. We chose to enroll herds from these regions as the Australian dairy industry is clustered in these areas. At the time that fieldwork commenced (2011), there were 6,770 dairy herds in Australia, with 4,556 (67.3\%) located in Victoria and 444 (6.6\%) in Tasmania, meaning this survey was conducted in regions that contained $73.9 \%$ of Australia's dairy herd. The average herd size of Victorian and Tasmanian dairy herds in 2011 was 232 and 328 cows, respectively. In 2011, the average bulk milk SCC in Australian dairy herds was 232,000 cells $/ \mathrm{mL}$, based on records from 5,976 herds. Of these, $61.0 \%$ of herds were $\leq 250,000$ cells $/ \mathrm{mL}, 35.4 \%$ were $>250,000$ cells $/ \mathrm{mL}$ but $\leq 400,000$ cells $/ \mathrm{mL}$, and $3.5 \%$ were $>400,000$ cells $/ \mathrm{mL}$ (Taylor, 2021).

Participating veterinary clinics each selected 4 to 6 herds based on the following inclusion criteria: milking herd size $>250$ cows, previous year's bulk milk SCC 
averaging between 100,000 and 500,000 cells/mL, using electronic herd records, located within $50 \mathrm{~km}$ of the participating clinic, capable of delivering chilled milk samples to the participating clinic within $48 \mathrm{~h}$ of collection, and undertaking regular testing ( $>4$ tests per lactation) of individual cow SCC with a herd-testing organization. On admission to the study, herd managers were asked to complete a questionnaire with questions about farm size, their production system, ration fed, dry cow antibiotic and internal teat sealant use at dry-off, and number of cows culled due to mastitis the previous year.

\section{Recruitment of Samples}

Clinical Mastitis. Farmers were instructed to collect milk samples from the first 10 eligible cases of clinical mastitis during each month of the study $(n=13)$. Clinical mastitis was defined as visibly abnormal milk after 3 strips of foremilk (clots, discoloration, watery), inflammatory signs in affected glands (swelling, heat, pain, redness), or both. Cows with clinical mastitis were eligible for inclusion if they met the following criteria: currently lactating, not treated for mastitis in the previous $28 \mathrm{~d}$, not currently receiving treatment with antimicrobial agents or within the withholding period for antimicrobial treatments, and otherwise in good general health. Cows with multiple affected quarters were sampled in one quarter, which was decided by the farmer. Individual cows were eligible to be sampled in multiple months of the study.

Farm workers were instructed to collect milk samples using the following routine. With clean disposable gloves, farmers scrubbed teat ends with $70 \%$ isopropyl alcohol-soaked wipes until teat ends were clean (minimum $10 \mathrm{~s}$ ), discarded 2 squirts of foremilk, and sampled approximately 2 to $4 \mathrm{~mL}$ of milk into sterile vials. Gloves were washed or replaced between cows. Samples were immediately chilled at 2 to $8^{\circ} \mathrm{C}$ and delivered to the local clinic within $48 \mathrm{~h}$.

Subclinical Mastitis. Forty-seven participating farms also submitted milk samples from cows with subclinical mastitis at 1 or 2 sampling occasions during the 13-mo study period. Immediately after a herd test, data were downloaded by the study monitors. Infection was defined by a SCC above 250,000 as per Australian industry guidelines (Brightling et al., 2018). Cows were identified for sampling by study monitors from those with a range of SCC above the threshold (not just the highest), with a mix of "new" infections (as defined by a low previous SCC during lactation) and "old" infections (SCC had been elevated at prior herd tests conducted during current lactation), from a range of cow ages and stages of lactation, with the exception of cows in very early lactation. Lists of suitable cows were sent to the farm and as many nominated cows were sampled as possible. Sampling method was the same as for clinical mastitis cows, except that composite samples were collected (i.e., milk from all functional quarters commingled into a single sample).

\section{Bacteriology}

Aerobic Culture. After arrival at the local veterinary clinic, milk samples were shipped immediately to an accredited (National Association of Testing Authorities, Australia) commercial veterinary diagnostic laboratory (Gribbles Veterinary Pathology, Clayton, Victoria, Australia). Samples were inoculated onto Columbia agar with $5 \%$ sheep blood with 1 loop-full (approximately $10 \mu \mathrm{L}$ ) of sample using disposable plastic loops and then incubated in aerobic conditions at $37 \pm$ $2^{\circ} \mathrm{C}$ for $48 \mathrm{~h}$. Isolates were identified using growth characteristics on blood agar, microscopic appearance after staining (Gram and Giemsa), and biochemical testing. We identified Staph. aureus using catalase, coagulase (latex agglutination), and DNase activity. Grampositive, catalase-negative species were identified using hemolytic patterns and Lancefield group testing, with group B isolates classified as Strep. agalactiae, group C isolates classified as Strep dysgalactiae, and nongrouping isolates classified as Strep. uberis. Isolates classified as group B that had an atypical appearance (i.e., colonies were not hemolytic) were subject to further testing using the Christie-Atkins-Munch-Petersen (CAMP) test and Streptococcus API (bioMerieux Australia Pty Ltd.). Gram-negative isolates were identified using oxidase, indole, and Microbact gram-negative test kits (ThermoFisher). Corynebacterium bovis and Listeria monocytogenes were identified using API (bioMerieux Australia Pty Ltd.) along with colony morphology and first principles identification. Trueperella pyogenes were identified using Loeffler's slope. No specialized culture medium and incubator settings were used for isolation of Mycoplasma spp. Mixed growths (i.e., 2 or more isolates from a single sample) were usually classified as contaminated. However, in situations when more than 1 mastitis pathogen was present in heavy growth in a milk sample, it was identified and reported but managed as a separate sample from the same cow. Consequently, only 1 mastitis pathogen was recorded for each sample.

Antimicrobial Susceptibility. Antimicrobial susceptibility was determined on each isolate using disk diffusion, according to methods described in the Clinical and Laboratory Standards Institute (CLSI) performance standards for antimicrobial disk and dilution susceptibility tests for bacteria isolated from animals-third edition (Watts et al., 2008). Isolates were 
transferred after 18 to $24 \mathrm{~h}$ of growth onto MuellerHinton agar using a sterile swab and a 0.5 McFarland turbidity reference standard suspension. Antimicrobialimpregnated paper disks were applied with a dispenser. Susceptibility was evaluated for amoxicillin-clavulanic acid (20 and $10 \mu \mathrm{g}$, respectively), amoxicillin (20 $\mu \mathrm{g})$, cefuroxime $(30 \mu \mathrm{g})$, cloxacillin $(5 \mu \mathrm{g})$, neomycin (30 $\mu \mathrm{g})$, penicillin-novobiocin (10 and $30 \mu \mathrm{g}$, respectively), penicillin $(10 \mu \mathrm{g})$, streptomycin $(10 \mu \mathrm{g})$, tetracycline $(30 \mu \mathrm{g})$, and trimethoprim-sulfamethoxazole $(1.25$ and $23.75 \mu \mathrm{g}$, respectively). These antimicrobial agents were chosen to match the antimicrobials used to treat and control mastitis in Australia (Taylor, 2021; Supplemental Table S1; https://osf.io/dfq7p). Different antimicrobial panels were used for pathogen groups according to testing protocols at the laboratory. Staphylococcus aureus isolates had susceptibility determined for amoxicillin, cefuroxime, cloxacillin, erythromycin, neomycin, penicillin, penicillin-novobiocin, tetracycline, and trimethoprim-sulfamethoxazole. Streptococcus spp. isolates had susceptibility determined for amoxicillin, cefuroxime, cloxacillin, erythromycin, penicillin, penicillin-novobiocin, tetracycline, and trimethoprim-sulfamethoxazole. Isolates belonging to the family Enterobacteriaceae had susceptibility determined for amoxicillin (excluding Escherichia coli and Serratia spp.), amoxicillin-clavulanate (excluding Serratia spp.), cefuroxime (excluding Serratia spp.), neomycin, streptomycin, tetracycline, and trimethoprim-sulfamethoxazole. Pasteurella spp. isolates had susceptibility determined for amoxicillin, amoxicillin-clavulanate, cefuroxime, penicillin, tetracycline, and trimethoprim-sulfamethoxazole. Zones of inhibition were visually measured using a ruler, and isolates were initially classified as susceptible, intermediate, or resistant based on CLSI recommendations. Quality control evaluation of zone inhibition diameters against reference isolates was undertaken weekly according to CLSI protocols. Resistance was classified as nonsusceptibility by combining intermediate and resistant groups into a single category (Nobrega et al., 2018b). Breakpoints for classification as susceptible for each bacterial isolate and antimicrobial combination are provided in Supplemental Table S2 (https://osf.io/ dfq7p; Taylor, 2021). Methicillin susceptibility testing was not performed for any isolates, which prevented us from identifying the presence or absence of methicillin resistance. Antimicrobial susceptibility was not assayed for CNS.

\section{Statistical Analysis}

Statistical analyses were conducted using SAS for Windows version 9.4 (SAS Institute Inc.). The number and percentage of each pathogen identified was summarized for clinical and subclinical isolates overall and stratified by region. Pathogen profiles based on percentages were also calculated at the herd level for herds that had $\geq 20$ valid (i.e., noncontaminated) clinical samples. Prevalence and exact 95\% confidence intervals (Clopper-Pearson confidence limits) for the AMR were presented for E. coli, Serratia spp., Staph. aureus, Strep. dysgalactiae, and Strep. uberis for clinical and subclinical isolates and for Klebsiella spp. and Pasteurella spp. for clinical isolates only. Trends in plots were explored visually.

As an exploratory analysis, the risk of AMR was compared between clinical and subclinical isolates for pathogen-antimicrobial combinations. This was only conducted for pathogen-antimicrobial combinations that had enough data to avoid issues with positivity [i.e., at least 20 clinical and 20 subclinical isolates and AMR prevalence of $>0.01$ (1\%) in clinical or subclinical groups]. Consequently, the pathogen-antimicrobial combinations that were eligible for this exploratory analysis were as follows: Staph. aureus - penicillin (model 1), Staph. aureus - amoxicillin (model 2), Staph. aureus - erythromycin (model 3), Strep. dysgalactiae - erythromycin (model 4), Strep. dysgalactiae - tetracycline (model 5), Strep. uberis - erythromycin (model 6), and Strep. uberis - tetracycline (model 7). No adjustments were made for multiple comparisons.

In each case, the binary outcome variable denoting resistance was analyzed with a generalized linear mixed model with a Poisson distribution and log link. Poisson models were used to achieve estimates of risks and relative risks, rather than odds and odds ratios (Ospina et al., 2012). The model terms included the fixed effect of mastitis type (clinical or subclinical) and the random effect of farm. A random effect for cow was not included in final models because it was very uncommon to have multiple isolates per cow for each antibioticpathogen combination. No adjustments were made to address temporal clustering. Estimated risks have been presented for each mastitis type, along with the relative risk (with 95\% CI) of a resistant result for subclinical samples compared with clinical samples.

\section{RESULTS}

\section{Description of Enrolled Herds}

The response rate to individual questions within the herd-demographics questionnaire ranged from 52 $(80.0 \%)$ to $65(100.0 \%)$. Average peak herd size (the maximum number of milking cows in the herd during the study period) was 464 cows (range 210-1,000; 64/65 
Table 1. Pathogen profile for clinical mastitis samples from 65 southeastern Australian dairy farms collected between January 2011 and March 2012 , stratified by region

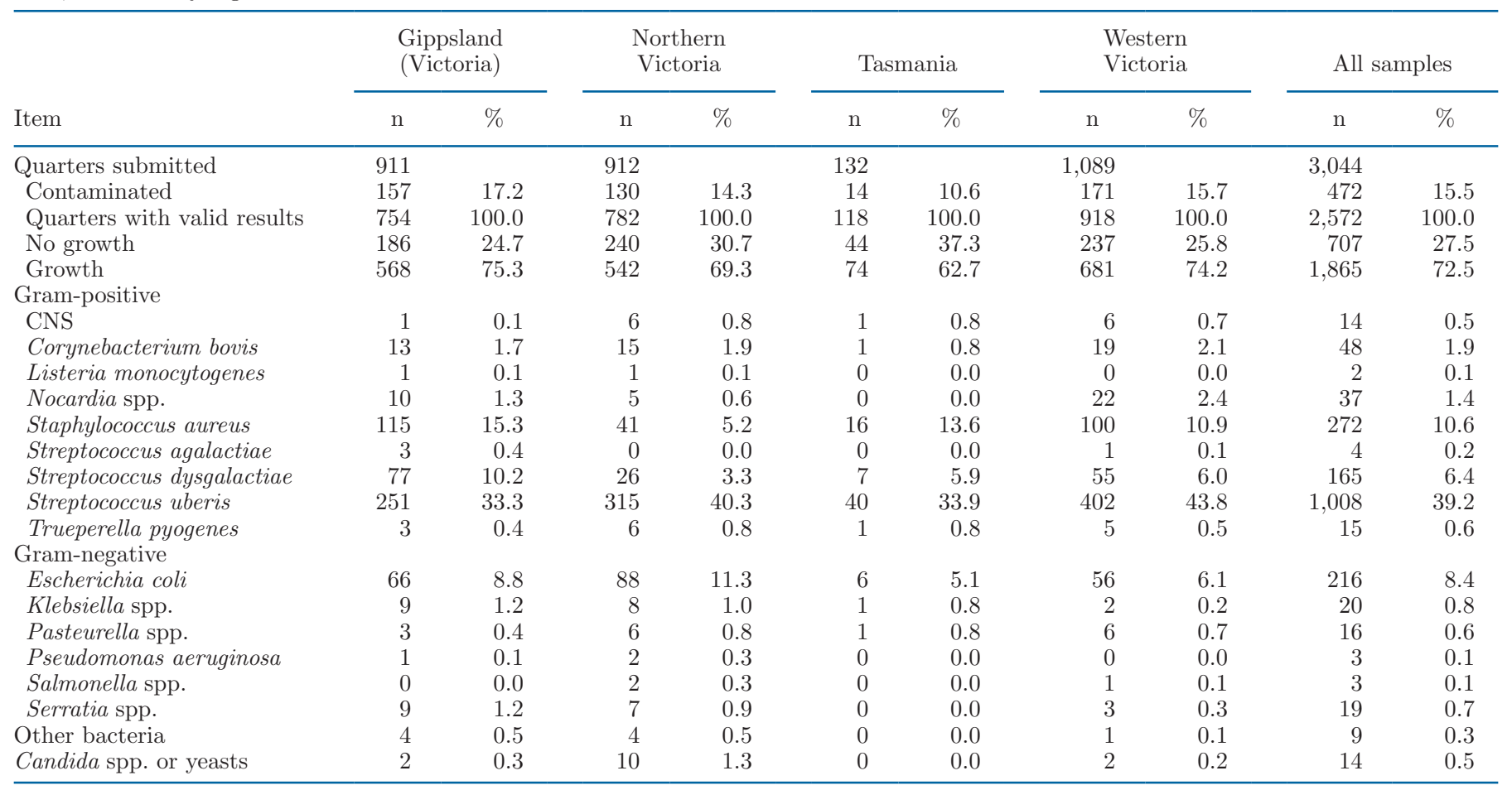

herds responded). Of the 52 farms reporting their calving pattern, $31(59.6 \%)$ were classified as split calving $(<3$ calving groups/year), $16(30.8 \%)$ were seasonal (the whole herd calved over a $2-3$ mo period at the same time each year), $4(7.7 \%)$ were year-round calving, and $1(1.9 \%)$ was batch calving ( $>3$ calving groups per year). Herds reported using rotary $(54.7 \%)$ and herringbone $(45.3 \%$, cows stand at various angles up to 90 degrees to the pit) parlors (64/65 herd response). The most common feeding system was a combination of grazed pasture and grain-based concentrates fed in the milking parlor $(64.1 \%)$, followed by partial mixed ration $(26.6 \%)$, grazing-only $(7.8 \%)$, and TMR (1.6\%). Of the 60 farmers who reported the active agent in their teat sprays, all used an iodophore-based teat spray for postmilking teat disinfection. Of the 61 farmers reporting dry-off practices in the previous season, $85.2 \%$ and $14.8 \%$ practiced whole-herd (blanket) and part-herd (selective) dry cow therapy, respectively. Of 62 farmers who described the antimicrobial dry cow product used in the previous season, $75.8 \%$ used a cloxacillin-only product, $9.7 \%$ used both cloxacillin or cephalonium, $12.9 \%$ used cephalonium only, and $1.6 \%$ used either an ampicillin-cloxacillin combination product or cephalonium. Of 58 farms that reported on the use of an internal teat sealant on their farm, $56.9 \%$ used an internal teat sealant as part of the drying off strategy.

\section{Clinical Mastitis}

A total of 3,073 quarter samples were submitted from cases of clinical mastitis from 65 different farms, but 29 records were excluded from all subsequent summaries as duplicate records (same date, animal and pathogen), leaving 3,044 unique samples as summarized in Table 1.

Description of Enrolled Cows and Cases. The 3,044 clinical samples came from 2,651 different cows as follows: 2,337 cows with a single sample, 69 cows with 2 to 3 different samples at 1 time point, and 245 cows with 1 or more samples at 2 to 5 different time points.

Clinical mastitis samples were submitted consistently throughout the first 12 mo of the survey at an average of 238 samples/month (range 140-378). Sample submissions were lower in the last 3 mo of the survey, averaging 65 samples/month. The average number of submissions per farm was 46.8 (range 5-197). Of 3,044 samples received from cows with clinical mastitis, 1,860 (61.1\%) were Holstein, 170 (5.6\%) were Jersey, 329 $(10.8 \%)$ were various crosses of Holstein and Jersey, 61 (2.0\%) were Aussie Reds (an Australian composite red dairy breed), and the remainder were a mix of purebred 
Brown Swiss, Illawarra (an Australian red dairy breed), Ayrshire, or various crosses of these breeds. Breed was unknown for 185 samples (6.1\%).

Based on 2,825 clinical mastitis samples submitted where the parity was recorded, $15.0 \%$ of cows were from first, $16.3 \%$ from second, $20.0 \%$ from third, $17.0 \%$ from fourth, $13.8 \%$ from fifth, $8.4 \%$ from sixth, and $9.5 \%$ from greater than seventh parity. Of 2,709 samples where stage of lactation was recorded, the number (\%) of samples submitted from each stage of lactation were 0 to $1 \mathrm{mo}(629,23.2 \%), 2$ to $6 \mathrm{mo}(1,268,46.8 \%)$, and $\geq 7$ mo $(812,30.0 \%)$. The lactation stage profiles for each region were similar, except for Tasmania, which included a higher proportion of samples submitted from cows at 0 to 1 mo postcalving $(53 / 99,53.5 \%)$.

Pathogen Profile. Of the 3,044 clinical mastitis samples, $472(15.5 \%)$ were excluded from analysis due to contamination. Of the remaining 2,572 samples with valid results, $707(27.5 \%)$ did not identify a pathogen using standard bacteriological methods (Table 1). Streptococcus uberis was the most common pathogen isolated from clinical mastitis samples, with $39.2 \%$ of valid results attributable to this bacterium. The next most common pathogens recorded were Staph. aureus, E. coli, and Strep. dysgalactiae, with $10.6 \%, 8.4 \%$ and $6.4 \%$ recorded respectively. Streptococcus agalactiae was only cultured from 4 clinical mastitis samples $(0.2 \%)$.

Prevalence of common pathogens (Strep. uberis, Staph. aureus, E. coli, Strep. dysgalactiae, Corynebacterium bovis) stratified by stage of lactation (0-1 mo, 2-6 mo, $7+$ months) can be found in Figure 1. Streptococcus uberis remained the dominant pathogen at all stages of lactation, which was isolated from $>35 \%$ of samples, regardless of stage of lactation. No clear trends of increasing or decreasing prevalence during lactation were

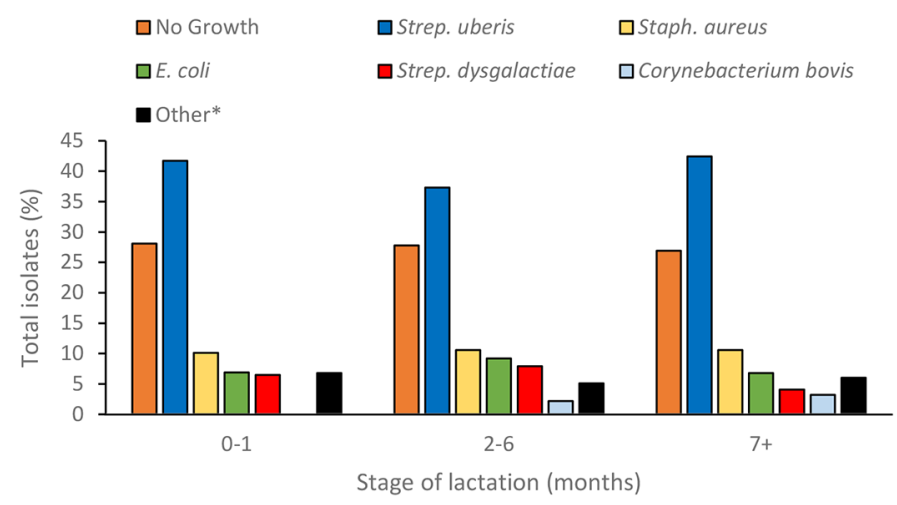

Figure 1. Histogram showing the percentage of the 6 most common culture results stratified by stage of lactation, grouped into the first month, mo 2 to 6 , and $>6$ mo of lactation. The remaining culture outcomes are grouped together as Other*. evident for Staph. aureus, E. coli, or Strep. dysgalactiae. Corynebacterium bovis was the only pathogen that displayed a trend of increasing prevalence during later lactation, accounting for 0 samples $(0.0 \%)$ in the first month of lactation, $2.2 \%$ of samples for 2 to 6 mo, and $3.2 \%$ in mo 7 or greater.

Pathogen profiles stratified by dairy region are shown in Table 1. The prevalence of Strep. uberis ranged from $33.3 \%$ in Gippsland to $43.8 \%$ in Western Victoria. Staphylococcus aureus prevalence ranged from $5.2 \%$ in Northern Victoria to $15.3 \%$ in Gippsland. Northern Victoria had the highest isolation rate of $E$. coli at $11.3 \%$, which made it the second most likely pathogen to be isolated from clinical mastitis samples submitted from that region.

Herd-Level Pathogen Profiles for Clinical Mastitis. Herd-level pathogen profiles are summarized for herds $(n=47)$ that had 20 or more valid culture results in Table 2. Among these herds, the average number of submissions per herd was $50.4(\mathrm{SD}=24.1$, range from 20-161). In the average herd, gram-positive pathogens were isolated from $60.5 \%$ of samples $(\mathrm{SD}=$ $14.2 \%$, range from $28.0-83.9 \%$ ), with $37 / 47$ (78.7\%) herds having gram-positive pathogens isolated from at least $50 \%$ of samples (Figure 2). Streptococcus uberis was a common pathogen in many herds (mean $=39.9 \%$ of samples, $\mathrm{SD}=14.7 \%$, range from $4.3-67.5 \%$ ). In the average herd, Staph. aureus and gram-negative pathogens accounted for 9.8\% (SD $=10.3 \%$, range $0.0-64.5 \%)$ and $11.3 \%(\mathrm{SD}=9.2 \%$, range $0.0-47.1 \%)$ of samples, respectively.

Antimicrobial Susceptibility for Pathogens Isolated from Cows with Clinical Mastitis. The prevalence (95\% CI) of AMR for clinical mastitis isolates is shown in Table 3. In general, AMR was uncommon among gram-positive pathogens. For Strep. uberis isolates, no AMR was identified for amoxicillin, cloxacillin, and penicillin. However, resistance was identified at a low prevalence against erythromycin $[0.07$ (i.e., $7 \%$ ) 95\% CI: $0.06,0.09]$ and tetracycline (0.01, 95\% CI: 0.01, 0.02). No clinical Staph. aureus isolates demonstrated resistance to cefuroxime, cloxacillin, penicillin-novobiocin, and trimethoprim-sulfamethoxazole. However, a small proportion of isolates were resistant to erythromycin $(0.03,95 \%$ CI: $0.02,0.06)$, amoxicillin (0.02, 95\% CI: $0.01,0.04)$, and penicillin (0.02, 95\% CI: 0.01, 0.04). Resistance among Strep. dysgalactiae isolates was identified against tetracycline $(0.90,95 \%$ CI: $0.85,0.94)$ and erythromycin $(0.07,95 \%$ CI: 0.03 , 0.12). Escherichia coli isolates demonstrated resistance to streptomycin and neomycin with prevalence at 0.36 (95\% CI: $0.29,0.43$ ) and 0.28 (95\% CI: $0.22,0.34)$, respectively. Klebsiella spp. isolates demonstrated a 


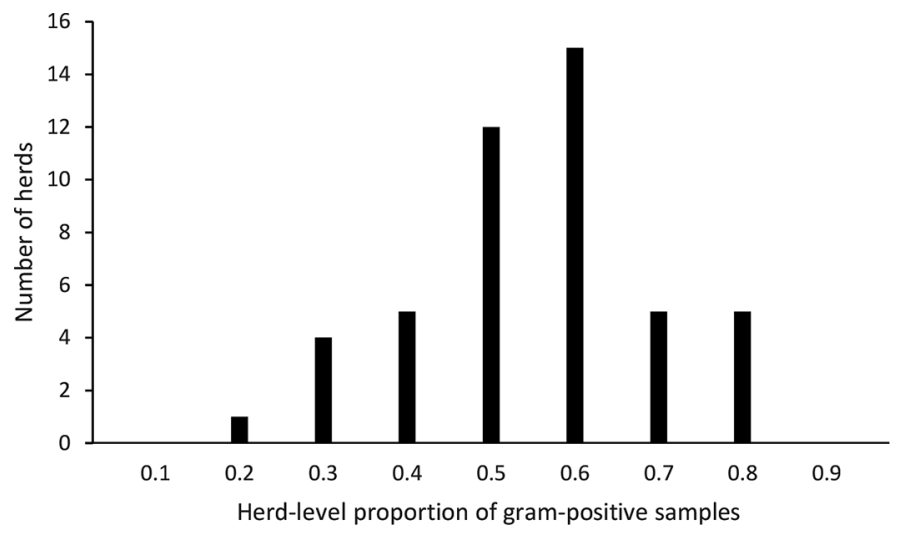

Figure 2. Histogram showing the herd-level prevalence of grampositive isolates from cows with clinical mastitis $(\mathrm{n}=2,367)$ on 47 southeastern Australian dairy farms collected between January 2011 and March 2012. The original data set consisted of 2,572 clinical mastitis samples from 65 herds, but samples from herds with $<20$ samples were excluded as they were expected to be an unreliable indicator of herd-level prevalence.

similar resistance profile to $E$. coli for most antimicrobials. Serratia spp. isolates had moderate to high levels of resistance to all antimicrobials evaluated, other than trimethoprim-sulfamethoxazole, where all isolates were susceptible. No AMR was identified for Pasteurella spp.

\section{Subclinical Mastitis}

Description of Enrolled Cows and Cases. A total of 1,079 composite milk samples were submitted from cases of subclinical mastitis (i.e., cows with elevated SCC) at 47 different farms, but 7 records were excluded from all subsequent summaries as they were duplicate records, leaving 1,072 samples for analysis. These 1,072 samples came from 1,026 cows, with 42 cows having 2 samples and 2 cows having 3. Most of these animals had 2 to 3 samples at one time point, with only 12 cows having 2 samples at different time points. Eight of 47 farms submitted samples on 2 occasions (i.e., in 2 different months).

Pathogen Profile. Culture results from 1,072 samples of subclinical mastitis, stratified by region, are summarized in Table 4. A total of 425 out of 1,072 $(39.6 \%)$ samples were excluded due to contamination. Of the remaining 647 valid results, 188 (29.1\%) yielded "no growth." Staphylococcus aureus was the organism most frequently isolated from subclinical mastitis samples $(\mathrm{n}=188,29.1 \%)$. Streptococcus uberis was the next most likely organism to be isolated ( $\mathrm{n}=$ 140, 21.6\%), whereas E. coli was only cultured on 10 occasions (1.5\%). The prevalence of valid subclinical mastitis culture results for Staph. aureus was highest in Tasmania at $56.3 \%$, and lowest in Northern Victoria at $21.0 \%$. Streptococcus uberis isolates were lowest in Tasmania at $18.8 \%$ and highest in Gippsland at $24.3 \%$.

Antimicrobial Susceptibility for Pathogens Isolated from Cows with Subclinical Mastitis. Prevalence of AMR for a selection of subclinical mastitis isolates including E. coli, Serratia spp., Staph. aureus, Strep. dysgalactiae, and Strep. agalactiae are

Table 2. Herd-level pathogen profile for clinical mastitis samples from $47^{1}$ southeastern Australian dairy farms collected between January 2011 and March 2012

\begin{tabular}{lrrrr}
\hline Item & Average & SD & Min & Max \\
\hline Quarters with valid results (n) & 50.4 & 24.1 & 20.0 & 161.0 \\
No growth (\%) & 27.5 & 12.2 & 4.8 & 60.9 \\
Gram-positive (\%) & 60.5 & 14.2 & 28.0 & 83.9 \\
CNS (\%) & 0.7 & 1.3 & 0.0 & 4.5 \\
Corynebacterium bovis (\%) & 1.6 & 2.4 & 0.0 & 12.0 \\
Listeria monocytogenes (\%) & 0.1 & 0.6 & 0.0 & 2.9 \\
Nocardia spp. (\%) & 1.7 & 2.1 & 0.0 & 10.7 \\
Staphylococcus aureus (\%) & 9.8 & 10.3 & 0.0 & 64.5 \\
Streptococcus agalactiae (\%) & 0.0 & 0.0 & 0.0 & 0.0 \\
Streptococcus dysgalactiae (\%) & 6.1 & 6.1 & 0.0 & 26.5 \\
Streptococcus uberis (\%) & 39.9 & 14.7 & 4.3 & 67.5 \\
Trueperella pyogenes (\%) & 0.6 & 1.2 & 0.0 & 4.5 \\
Gram-negative (\%) & 11.3 & 9.2 & 0.0 & 47.1 \\
Escherichia coli (\%) & 8.9 & 8.7 & 0.0 & 47.1 \\
Klebsiella spp. (\%) & 0.7 & 1.5 & 0.0 & 6.7 \\
Pasteurella spp. (\%) & 0.7 & 1.6 & 0.0 & 7.7 \\
Pseudomonas aeruginosa (\%) & 0.1 & 0.6 & 0.0 & 3.3 \\
Salmonella spp. (\%) & 0.1 & 0.5 & 0.0 & 3.2 \\
Serratia spp. (\%) & 0.7 & 1.1 & 0.0 & 4.4 \\
Other bacteria (\%) & 0.3 & 0.8 & 0.0 & 4.2 \\
Candida spp. or yeasts (\%) & 0.5 & 1.2 & 0.0 & 4.7 \\
\hline
\end{tabular}

${ }^{1}$ The original data set consisted of 2,572 valid results from clinical mastitis samples from 65 herds, but samples from herds with $<20$ samples were excluded $(\mathrm{n}=205,8.0 \%)$. 


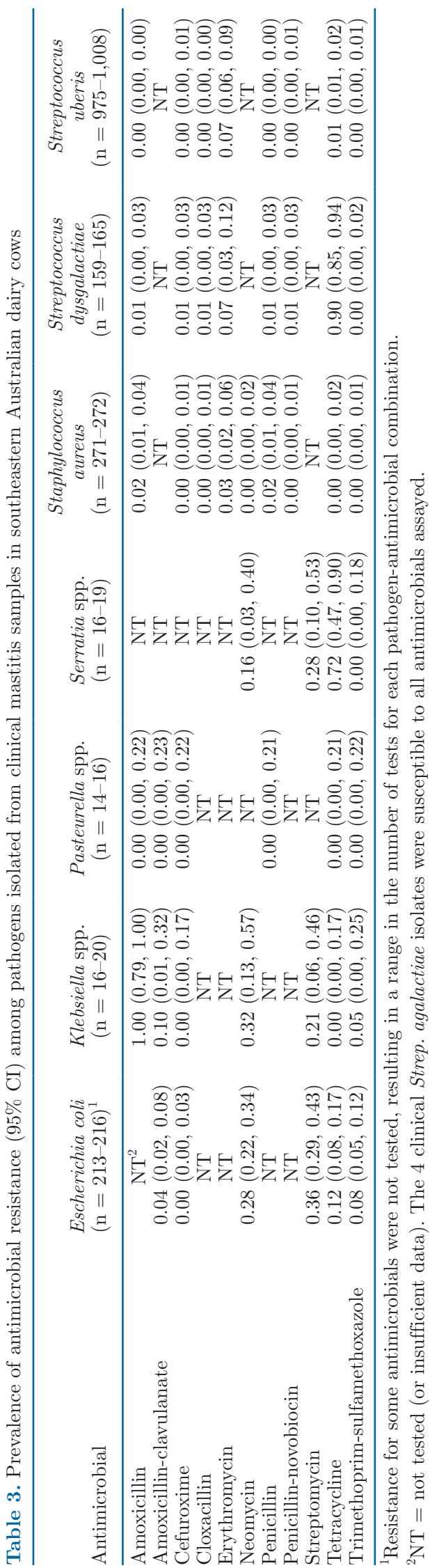

shown in Table 5. Staphylococcus aureus isolates demonstrated some resistance against penicillin $(0.15,95 \%$ CI: $0.10,0.21)$ and amoxicillin $(0.14,95 \%$ CI: 0.09 , 0.20), whereas Strep. uberis isolates demonstrated resistance to erythromycin $(0.07,95 \%$ CI: $0.03,0.12)$ and tetracycline $(0.03,95 \%$ CI: 0.01, 0.07). Antimicrobial resistance against tetracycline was common among Strep. dysgalactiae isolates $(0.72,95 \%$ CI: $0.53,0.86)$.

Only a small number of gram-negative isolates were available for analysis, including E. coli $(\mathrm{n}=9)$ and Serratia spp. $(\mathrm{n}=4)$. For E. coli, AMR was identified against neomycin (0.44, 95\% CI: 0.14, 0.79), streptomycin $(0.44,95 \%$ CI: $0.14,0.79)$, tetracycline $(0.11,95 \%$ CI: $0.00,0.48)$, and trimethoprim-sulfamethoxazole (0.11, 95\% CI: 0.00, 0.48). Serratia spp. isolates demonstrated some resistance to antimicrobials other than trimethoprim-sulfamethoxazole, with AMR prevalence ranging from 0.25 to 1.00 .

\section{Comparison of AMR in Clinical and Subclinical Isolates}

Effect estimates from 7 generalized linear mixed models describing the relationship between infection type (clinical vs subclinical) and risk of AMR are shown in Table 6. The risk of Staph. aureus demonstrating resistance to penicillin was 5.16 (95\% CI: 1.68, 15.88) times higher in isolates collected from cows with subclinical mastitis than those from clinical isolates and 4.70 (95\% CI: 1.49, 14.75) times higher for amoxicillin. The remaining models for Staph. aureus (erythromycin), Strep. dysgalactiae (erythromycin, tetracycline) and Strep. uberis (erythromycin, tetracycline) did not identify a significant association between infection type and resistance.

\section{DISCUSSION}

\section{Streptococcus uberis Is the Most Common Mastitis-Causing Pathogen on Southeastern Australian Dairy Farms}

The results from this study indicated that Strep. uberis was the most important mastitis-causing pathogen on southeastern Australian dairy farms (39.2\% of samples). This finding is consistent with smaller surveys of dairy herds in the Gippsland region, which found that Strep. uberis was isolated from 22.7\% (Watson et al., 1996) and 26.6\% (Gunn et al., 1999) of clinical mastitis samples. This finding is also consistent with surveys conducted in pasture-based dairy herds in New Zealand, which found that Strep. uberis was isolated from 23.3\% (Petrovski et al., 2009) and 33.8\% (McDougall et al., 2007b) of clinical mastitis samples. Our find- 
Table 4. Pathogen profile for subclinical mastitis samples from 47 southeastern Australian dairy farms collected between April 2011 and March 2012 , stratified by region

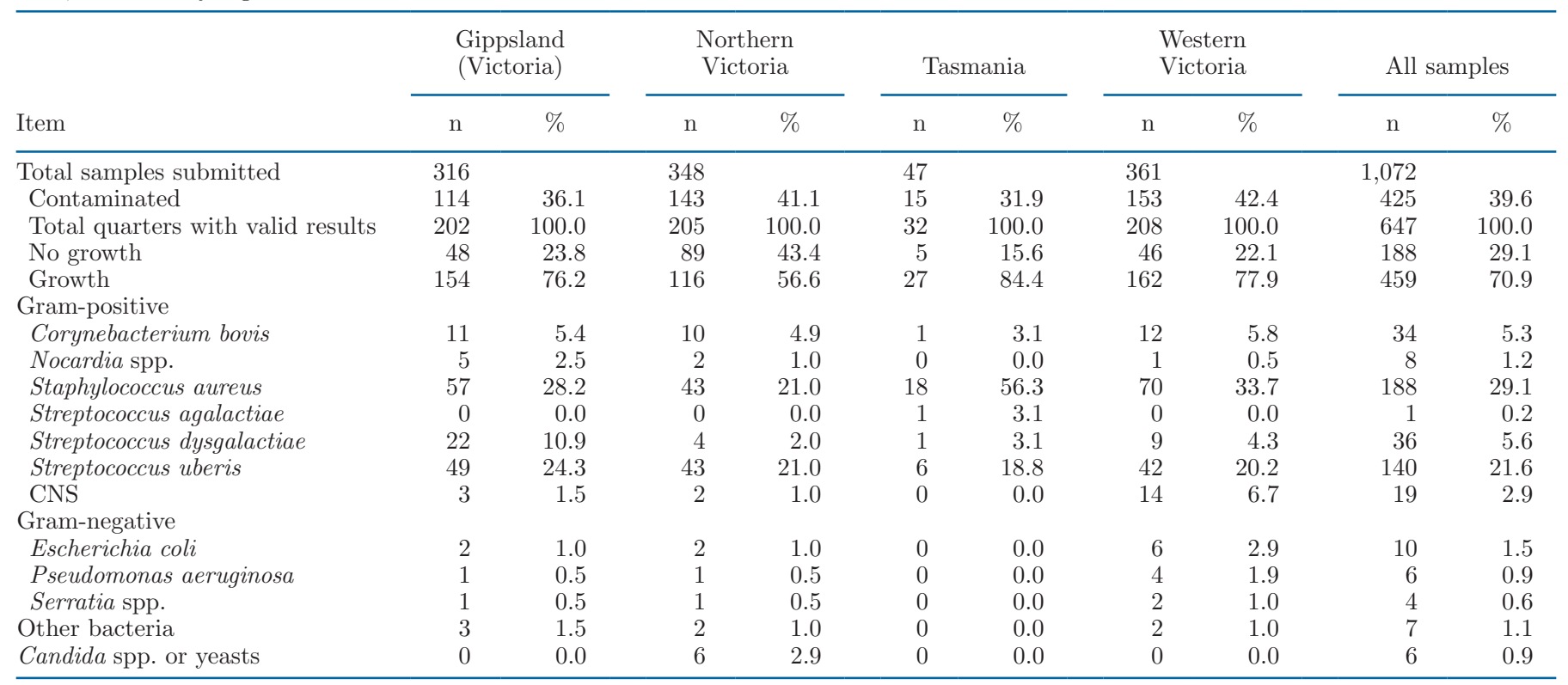

ings indicated that Staph. aureus ( $10.6 \%$ of samples) remains a relatively common cause of clinical mastitis in Australian dairy herds, although the proportion of samples associated with this pathogen was lower than in historical studies, which found higher proportions of Staph. aureus at 38.5\% (Daniel et al., 1982) and 26.3\% (Watson et al., 1996). This apparent reduction in prevalence is likely due to ongoing mastitis control strategies promoted through Dairy Australia's mastitis control program (Brightling et al., 2018).

"No growth" was a common outcome in this study, occurring in $27.5 \%$ of samples. However, this finding was lower than in 2 previous surveys of mastitis patho- gens in pasture-fed dairy cattle where "no growth" was reported in 38.7\% (Daniel et al., 1982) and 34.4\% (Gunn et al., 1999) of samples, and slightly higher than another Australian study by Shum et al. (2009) where "no growth" was reported in $24.4 \%$ of samples. Falsenegative results (i.e., pathogens not being isolated in milk from an infected quarter) can be due to pathogens being killed by the inflammatory response within the mammary gland before sample collection (Erskine and Bartlett, 1993; Vangroenweghe et al., 2004) and due to unfavorable storage (Schukken et al., 1989) or culture conditions. In addition to these constraints, infections caused by Mycoplasma spp. cannot be readily identified

Table 5. Prevalence of antimicrobial resistance (95\% CI) among pathogens isolated from subclinical mastitis samples in southeastern Australian dairy cows

\begin{tabular}{|c|c|c|c|c|c|}
\hline Antimicrobial & $\begin{array}{l}\text { Escherichia coli } \\
\qquad(\mathrm{n}=6-9)^{1}\end{array}$ & $\begin{array}{l}\text { Serratia spp. } \\
\quad(\mathrm{n}=4)\end{array}$ & $\begin{array}{c}\text { Staphylococcus } \\
\quad \text { aureus } \\
(\mathrm{n}=154-183)\end{array}$ & $\begin{array}{c}\text { Streptococcus } \\
\text { dysgalactiae } \\
(\mathrm{n}=31-32)\end{array}$ & $\begin{array}{c}\text { Streptococcus } \\
\text { uberis } \\
(\mathrm{n}=134-138)\end{array}$ \\
\hline Amoxicillin & $\mathrm{NT}^{2}$ & NT & $0.14(0.09,0.20)$ & $0.00(0.00,0.11)$ & $0.00(0.00,0.03)$ \\
\hline Cefuroxime & $0.00(0.00,0.46)$ & NT & $0.00(0.00,0.02)$ & $0.00(0.00,0.11)$ & $0.00(0.00,0.03)$ \\
\hline Cloxacillin & NT & NT & $0.00(0.00,0.02)$ & $0.00(0.00,0.11)$ & $0.00(0.00,0.03)$ \\
\hline Erythromycin & NT & NT & $0.03(0.01,0.07)$ & $0.03(0.00,0.16)$ & $0.07(0.03,0.12)$ \\
\hline Streptomycin & $0.44(0.14,0.79)$ & $0.75(0.19,0.99)$ & NT & NT & NT \\
\hline Tetracycline & $0.11(0.00,0.48)$ & $1.00(0.40,1.00)$ & $0.00(0.00,0.02)$ & $0.72(0.53,0.86)$ & $0.03(0.01,0.07)$ \\
\hline Trimethoprim- sulfamethoxazole & $0.11(0.00,0.48)$ & $0.00(0.00,0.60)$ & $0.00(0.00,0.02)$ & $0.00(0.00,0.11)$ & $0.00(0.00,0.03)$ \\
\hline
\end{tabular}


Table 6. Results from 7 generalized linear mixed models ${ }^{1}$ comparing antimicrobial resistance in bacteria isolated from cows with clinical and subclinical mastitis

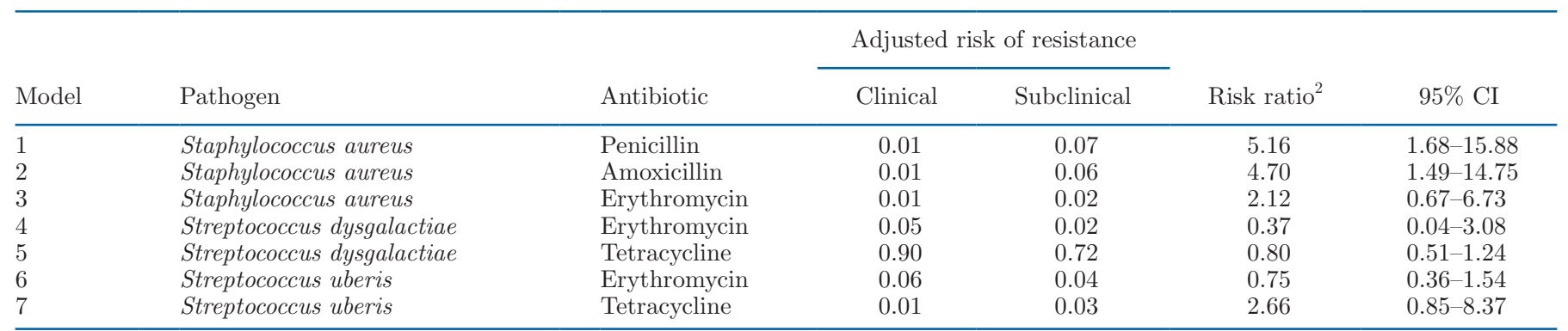

${ }^{1}$ Models to compare clinical and subclinical samples, with random effects used to account for the clustering of samples within farms.

${ }^{2}$ The risk of resistance in subclinical samples divided by the risk in clinical isolates. For example, a risk ratio for model 1 indicates that the risk of penicillin resistance for Staph. aureus was 5.16 times higher in isolates collected from cows with subclinical mastitis, than cows with clinical mastitis.

using standard aerobic culture, the method used in this study. Therefore, it remains unknown what proportion of cases of clinical mastitis in Australian herds are due to Mycoplasma spp. infections.

The proportion of contaminated samples in the current study was relatively high, especially for subclinical isolates. This may be due to improper sampling methods by producers. However, it was also likely due to the use of a relatively strict definition for contamination (i.e., 2 or more isolates $=$ contaminated). This is supported by surveys that have identified mixed infections in 2.7\% (Olde Riekerink et al., 2008) and 6.6\% (Shum et al., 2009) of clinical mastitis cases. A recent survey of late-lactation cows without clinical mastitis identified that $1.4 \%$ of quarters were infected with 2 pathogens (Rowe et al., 2019) and that $38.8 \%$ of cows had 2 or more infected quarters (Rowe et al., 2021). Therefore, it is likely that some "contaminated" composite samples from subclinical mastitis samples were mixed infections rather than contaminated. Consequently, omitting isolates from presumed contaminated samples could have resulted in the recruitment of isolates that differed from the actual pathogen profile in Australian herds, which could cause selection bias and reduce generalizability of our findings.

\section{Pathogen Profiles Are Similar in Pastured-Based Herds in Australia and New Zealand}

Our findings indicated that the pathogen profile for southeastern Australian dairy herds is likely to be similar to pasture-based herds in New Zealand, but different to herds managed in confinement systems in New South Wales (Shum et al., 2009), the United States (Lago et al., 2011), and Canada (Olde Riekerink et al., 2008), where gram-negative pathogens are much more common. This difference may be due to dietary factors influencing the fecal shedding of coliforms in cows that are housed and fed a TMR (Tkalcic et al., 2000). Likewise, pasture-fed dairy cows are exposed to laneways and pastures that become heavily contaminated with Strep. uberis during wet conditions (Lopez-Benavides et al., 2007), which are common around the time of calving in pasture-fed dairy herds in southeastern Australia and New Zealand. One of the main strategies to manage environmental mastitis is the use of internal teat sealants at dry-off to prevent intramammary infection during the dry period (Runciman et al., 2010). Although $56.9 \%$ of participants in this survey reported the use of an internal teat sealant at dry-off, adoption of this nonantimicrobial mastitis control strategy has likely increased since this study was conducted.

\section{Clinical Mastitis Pathogen Profiles Varied Among Herds}

The profile of pathogens associated with clinical mastitis varied among herds (Table 2). For example, the percentage of samples from each herd that isolated Staph. aureus ranged from 0.0 to $64.5 \%$, whereas the range for $E$. coli herd prevalence was 0.0 to $47.1 \%$. This variability indicated that the "average" herd in this study was unlikely to be representative of all Australian herds. Therefore, we recommend that producers build their own pathogen profile by submitting samples to a veterinary diagnostic laboratory. Gram-positive pathogens were isolated from $60.5 \%$ of samples in the "average" herd in this study, with a range from 28.0 to $83.9 \%$, with 37 out of $47(78.7 \%)$ herds having gram-positive pathogens isolated from at least $50 \%$ of samples. This finding indicated that in the average herd, a selective treatment strategy, which typically reserves antimicrobial therapy for cases yielding gram-positive pathogens (Lago et al., 2011; McDougall et al., 2018; Fuenzalida 
and Ruegg, 2019a,b), could theoretically reduce antimicrobial use by $39.5 \%$, ranging from $16.1 \%$ (i.e., the herd with the largest proportion of cases caused by grampositive pathogens) to $72.0 \%$. This hypothesis requires further investigation because cases without a diagnosis (i.e., those not sampled or with inconclusive results due to contamination) are treated along with grampositive cases. Furthermore, the herd-level pathogen profiles identified in this study were based on a variable number of samples from each herd, and diagnoses were obtained using laboratory-based aerobic culture, and not on-farm testing. Recent clinical trials in New Zealand, a region with similar pathogen profiles to those observed in this study, have found that selective treatment strategies based on rapid culture (McDougall et al., 2018) or a novel colorimetric test (Bates et al., 2020) reduced antimicrobial use by 25 and $24 \%$, respectively, which is significantly less than the hypothetical number identified in this study. Given the increasing need to refine how antimicrobials are used on dairy farms, we believe more research is needed to evaluate the effect of implementing selective treatment strategies for clinical mastitis on antimicrobial use and cow health in Australian herds. Furthermore, partial budget analyses are needed to evaluate the cost-effectiveness for selective treatment strategies implemented under economic conditions seen on dairy farms in Australia, as has been done in other countries (Pinzón-Sánchez et al., 2011; Down et al., 2017).

\section{Prevalence of AMR Was Low for Common Pathogens}

In this study, pathogens that were commonly isolated from cows with clinical (Table 3) and subclinical (Table 5) mastitis (i.e., Strep. uberis, Staph. aureus, and Strep. dysgalactiae) were rarely resistant to antimicrobials that are commonly used for mastitis control in Australian dairy herds, which are listed in Supplemental Table S1 (https://osf.io/dfq7p; Taylor, 2021). Surveys of mastitis pathogens conducted in other countries have found similarly low (Bengtsson et al., 2009) or higher prevalence of AMR to the antimicrobials evaluated in this study among the same pathogens (Makovec and Ruegg, 2003; McDougall et al., 2014; Cheng et al., 2019). However, methods for identifying AMR vary among studies, making direct comparisons problematic. The findings from this study suggested that decades of antimicrobial use within the Australian dairy industry for mastitis control appear to have had little effect on AMR development. This conclusion is supported by a review by Oliver et al. (2011), which failed to find consistent evidence of an emerging trend of AMR among mastitis pathogens. However, our findings may not be applicable in countries where AMR is more common in mastitis pathogens (Kalmus et al., 2011).

There were some instances in the current study where AMR was identified for some pathogen-antimicrobial combinations. For example, among both clinical and subclinical isolates of E. coli, Klebsiella spp., and Serratia spp., resistance was documented to streptomycin and neomycin to varying degrees. Antimicrobial susceptibility for these same antimicrobials were not evaluated against all pathogens, so it was not possible to determine if this resistance was evident across a broader range of pathogens.

For clinical and subclinical isolates of Strep. dysgalactiae, there was a high prevalence of resistance identified to tetracycline. This finding is consistent with studies conducted in New Zealand (Petrovski et al., 2011), Belgium, (Supré et al., 2014), and Canada (Cameron et al., 2016), where $88.8,93.2$, and $82.2 \%$ of isolates of Strep. dysgalactiae, respectively, were classified as resistant to tetracycline. Cameron et al. (2016) concluded that this is likely to be a common finding with this pathogenantimicrobial combination due to the common use of tetracyclines to treat a range of infections of cattle (and humans), mobility of genetic determinants of tetracycline resistance between bacterial genera, and hosts and apparent persistence of tetracycline resistance in the absence of selection pressure. However, levels of tetracycline resistance in Strep. uberis identified in these 3 studies varied, with this study and the New Zealand study finding low levels of tetracycline resistance, and Cameron et al. (2016) finding very high levels of tetracycline resistance in both Strep. uberis and Strep. dysgalactiae. This requires further exploration in future studies, but may be due to variation in the proportion of this organism which is maintained in the environment, versus being cow-associated and thus exposed to systemic treatments with tetracycline used to treat other conditions (Nobrega et al., 2018a). Streptococcus uberis and Strep. dysgalactiae isolates in this study also demonstrated some resistance to erythromycin.

However, levels of penicillin and amoxicillin resistance in clinical Staph. aureus isolates in this study appear to be lower than levels reported by Daniel et al. (1982). The same trend of decreasing levels of penicillin resistance in this pathogen has been noted in New Zealand (McDougall et al., 2014) and the United States (Pol and Ruegg, 2007). The absence of high prevalence of AMR among Staph. aureus isolates in Australian dairy cattle is further supported by a study conducted in 2013 that found no evidence of methicillin resistance in 203 Staph. aureus isolates from mastitis submissions to 22 Australian veterinary diagnostic laboratories (Worthing et al., 2018). 
The low AMR prevalence among common pathogens suggests that transfer of AMR from mastitis pathogens to humans under Australian conditions is unlikely. However, it should be noted that microorganisms other than recognized mastitis pathogens (e.g., those from the gastrointestinal tract) can also contaminate milk via the teat surface at milking, or enter the udder via environmental contamination, and may be potential sources of AMR. Another limitation is that our study did not focus on AMR pathogens that are commonly a problem in public health (e.g., methicillin-resistant Staph. aureus, extended spectrum $\beta$-lactamase producing Enterobacteriaceae). Therefore, more research is needed in Australian dairy herds to investigate the prevalence of AMR in bulk milk.

\section{AMR and Antimicrobial Therapy for Clinical Mastitis}

The predominance of gram-positive pathogens with low AMR prevalence in this study indicated that treatment outcomes for clinical mastitis may be similar among the products currently registered for mastitis treatment in Australia, assuming that AMR defined with human breakpoints is correlated with the outcome of antimicrobial therapy. This hypothesis is supported by several clinical trials conducted in New Zealand (where pathogen profiles are similar to those in Australia), showing similar responses to treatment (bacteriological cures, clinical cures) among antimicrobial treatments (McDougall, 1998, 2003; McDougall et al., 2007a; Bryan et al., 2016). In our opinion, antimicrobial stewardship could be improved on Australian dairy farms through the use of narrow-spectrum products (i.e., those targeting gram-positive pathogens only) that are administered via the intramammary route. Many factors other than antimicrobial susceptibility have been demonstrated to affect the probability of an infection curing after antimicrobial therapy, such as the ability of the pathogen to evade the immune response of the host, the chronicity of the infection (Melchior et al., 2006), and the duration of antimicrobial therapy (Truchetti et al., 2014).

\section{Staphylococcus aureus Isolates from Subclinical Mastitis Were More Likely to Have Resistance Against Penicillin and Amoxicillin Than Clinical Isolates}

One interesting finding from this study was that Staph. aureus isolates from subclinical mastitis samples were 5.16 and 4.70 times more likely to have AMR for penicillin (0.07 vs. 0.01$)$ and amoxicillin (0.06 vs. 0.01$)$, respectively. Studies have demonstrated that antimicro- bial therapy is less successful at clearing IMI caused by Staph. aureus strains with mechanisms for AMR (Barkema et al., 2006). Therefore, it is plausible that the use of antimicrobial therapy during lactation and at dry-off may apply selection pressure to existing subclinical IMI within the herd, such that resistant strains of Staph. aureus are more likely to establish chronic infections and remain prevalent in the herd. The underlying mechanisms for this require further evaluation using data sets with sufficient detail to identify infection patterns, such as chronicity and responses to therapy. Furthermore, additional studies using molecular methods are needed to compare the mechanisms for AMR between clinical and subclinical isolates.

\section{Strengths and Limitations}

A major strength of this study was the large number of cows sampled $(\mathrm{n}=2,651)$ from a large number of herds $(\mathrm{n}=65)$ across multiple regions $(\mathrm{n}=4)$ in southeastern Australia, which is where $75 \%$ of the Australian dairy industry is concentrated. A limitation was the large time lag between the time of the fieldwork (2011-2012) and publication. We had not originally planned to publish this research due to finding similar pathogen profiles of earlier Australian studies (the primary objective of this study). However, we were recently motivated to do so by the recommendation to conduct AMR surveillance (WHO-OIE, 2016) and the opportunity to contribute a baseline to compare AMR in Australian dairy herds in the future. Given the time lag, it is possible that pathogen profiles and AMR patterns in Australian dairy cows have changed. Future studies are required, and the results from this survey will be useful to guide their design. However, recent studies conducted in New Zealand have found similar pathogen profiles (McDougall et al., 2018, 2019), suggesting that the findings from this study may still be representative for many herds in Australia.

Laboratory methods have also changed during this time. For example, isolates in the current study were identified using biochemical tests, such as catalase, coagulase, and Lancefield group testing, instead of MALDI-TOF, which has replaced the use of biochemical tests in many udder health laboratories. Therefore, it is possible that Enterococcus, Lactococcus, and Aerococcus species were misclassified as Streptococcus spp. (Murray, 2010). Furthermore, disk diffusion methodology was used to measure AMR, which is now more commonly evaluated using broth dilution methods. Disk diffusion provides good agreement with broth microdilution on classification of isolates of mastitis pathogens as susceptible or resistant (Saini et al., 2011), but MIC data 
allows more detailed monitoring of trends in AMR in bacterial populations over time through movement in the distribution of minimum inhibitory concentrations.

Panels of antimicrobials assayed for resistance varied among pathogens, as was the protocol at the laboratory. This limited our ability to make comparisons across pathogens for some antimicrobials. Another important limitation was that herds and cows were recruited by convenience sampling, rather than a probability sampling method. Therefore, it was possible for individual herds to submit more samples than others, which could bias the final estimates of pathogen prevalence. Furthermore, the inclusion criteria for samples with subclinical mastitis were broad, rather than samples being collected randomly from all eligible cows. Therefore, cows were likely enrolled according to the preferences of the producer, which may have favored selection of cows with a specific SCC dynamic (e.g., cows with recent increases in SCC or cows with chronically elevated SCC). Furthermore, samples were collected by farm workers rather than trained personnel, which is likely why the rate of contamination in this study was relatively high. Given that contamination status was unlikely to be associated with pathogen type, we doubt that the exclusion of contaminated samples from our data set caused selection bias.

\section{CONCLUSIONS}

The most common bacteria causing clinical mastitis in dairy herds in southeastern Australia is likely Strep. uberis, whereas Staph. aureus is likely to be the most common cause of subclinical mastitis. Despite decades of antimicrobial use to control these organisms, AMR appears to be uncommon.

\section{ACKNOWLEDGMENTS}

This study was funded by Pfizer Animal Health (now Zoetis Australia, Sydney, Australia). The staff of Gribbles Veterinary Pathology (Clayton, Victoria, Australia) and the participating veterinary practices, dairy farmers, and herd improvement organizations involved in this survey are all acknowledged for their assistance. N. Charman, A. Hodge, and L. Taylor were employed by Pifzer Animal Health at the time of this study. A. Hodge and L. Taylor are employees of Zoetis. The authors have not stated any other conflicts of interest.

\section{REFERENCES}

Barkema, H. W., Y. H. Schukken, and R. N. Zadoks. 2006. Invited review: The role of cow, pathogen, and treatment regimen in the therapeutic success of bovine Staphylococcus aureus mastitis. J. Dairy Sci. 89:1877-1895. https://doi.org/10.3168/jds.S0022 $-0302(06) 72256-1$.

Bates, A., R. Laven, O. Bork, M. Hay, J. McDowell, and B. Saldias. 2020. Selective and deferred treatment of clinical mastitis in seven New Zealand dairy herds. Prev. Vet. Med. 176:104915. https://doi .org/10.1016/j.prevetmed.2020.104915.

Bengtsson, B., H. E. Unnerstad, T. Ekman, K. Artursson, M. NilssonOst, and K. P. Waller. 2009. Antimicrobial susceptibility of udder pathogens from cases of acute clinical mastitis in dairy cows. Vet. Microbiol. 136:142-149. https://doi.org/10.1016/j.vetmic.2008.10 .024 .

Brightling, P., G. Mein, J. Malmo, D. Ryan, R. Dyson, M. Humphris, R. Moyle, E. Oakes, J. Penry, Z. Vogels, and P. Younis. 2018. Countdown Farm Guidelines for Mastitis Control, Dairy Australia Ltd. Accessed Sep. 17, 2021. https://www.dairyaustralia.com.au/ animal-management-and-milk-quality/mastitis-and-milk-quality/ mastitis/countdown-resources\#.YUQyurgzaUk.

Bryan, M. A., S. Hea, S. Mannering, and R. Booker. 2016. Demonstration of non-inferiority of a novel combination intramammary antimicrobial in the treatment of clinical mastitis. N. Z. Vet. J. 64:337-342. https://doi.org/10.1080/00480169.2016.1210044.

Cameron, M., M. Saab, L. Heider, J. T. McClure, J. C. RodriguezLecompte, and J. Sanchez. 2016. Antimicrobial susceptibility patterns of environmental streptococci recovered from bovine milk samples in the maritime provinces of Canada. Front. Vet. Sci. 3:79.

Cheng, J., W. Qu, H. W. Barkema, D. B. Nobrega, J. Gao, G. Liu, J. De Buck, J. P. Kastelic, H. Sun, and B. Han. 2019. Antimicrobial resistance profiles of 5 common bovine mastitis pathogens in large Chinese dairy herds. J. Dairy Sci. 102:2416-2426. https://doi.org/ $10.3168 /$ jds. 2018-15135.

Dairy Australia. 2021. Antimicrobial stewardship. Accessed Sep. 17, 2021. https://www.dairyaustralia.com.au/murray-dairy/animal -management-and-milk-quality/antimicrobial-stewardship \# .YUPMbbgzaUk.

Daniel, R. C., D. O'Boyle, M. S. Marek, and A. J. Frost. 1982. A survey of clinical mastitis in South-East Queensland dairy herds. Aust. Vet. J. 58:143-147. https://doi.org/10.1111/j.1751-0813 .1982.tb00625.x.

Down, P. M., A. J. Bradley, J. Breen, and M. J. Green. 2017. Factors affecting the cost-effectiveness of on-farm culture prior to the treatment of clinical mastitis in dairy cows. Prev. Vet. Med. 145:91-99. https://doi.org/10.1016/j.prevetmed.2017.07.006.

Erskine, R. J., and P. Bartlett. 1993. Serum concentrations of copper, iron, and zinc during Escherichia coli-induced mastitis. J. Dairy Sci. 76:408-413. https://doi.org/10.3168/jds.S0022-0302(93)77360 -9 .

Fuenzalida, M. J., and P. Ruegg. 2019a. Negatively controlled, randomized clinical trial to evaluate intramammary treatment of nonsevere, gram-negative clinical mastitis. J. Dairy Sci. 102:54385457. https://doi.org/10.3168/jds.2018-16156.

Fuenzalida, M. J., and P. Ruegg. 2019b. Negatively controlled, randomized clinical trial to evaluate use of intramammary ceftiofur for treatment of nonsevere culture-negative clinical mastitis. J. Dairy Sci. 102:3321-3338. https://doi.org/10.3168/jds.2018-15497.

Gunn, A. A., J. Malrno, G. A. Anderson, and I. W. Caple. 1999 The incidence of bacteria associated with clinical mastitis in the Macalister irrigation district. Pages 197-206 in Proc. Aust. Vet. Assoc. Hobart.

Halasa, T., K. Huijps, O. Osteras, and H. Hogeveen. 2007. Economic effects of bovine mastitis and mastitis management: A review. Vet. Q. 29:18-31. https://doi.org/10.1080/01652176.2007.9695224.

Kalmus, P., B. Aasmäe, A. Kärssin, T. Orro, and K. Kask. 2011. Udder pathogens and their resistance to antimicrobial agents in dairy cows in Estonia. Acta Vet. Scand. 53:4. https://doi.org/10.1186/ 1751-0147-53-4.

Lago, A., S. M. Godden, R. Bey, P. L. Ruegg, and K. Leslie. 2011. The selective treatment of clinical mastitis based on on-farm culture results: I. Effects on antibiotic use, milk withholding time, 
and short-term clinical and bacteriological outcomes. J. Dairy Sci. 94:4441-4456. https://doi.org/10.3168/jds.2010-4046.

Lopez-Benavides, M. G., J. H. Williamson, G. D. Pullinger, S. J. LacyHulbert, R. T. Cursons, and J. A. Leigh. 2007. Field observations on the variation of Streptococcus uberis populations in a pasturebased dairy farm. J. Dairy Sci. 90:5558-5566. https://doi.org/10 .3168/jds.2007-0194.

Makovec, J. A., and D. P. L. Ruegg. 2003. Antimicrobial resistance of bacteria isolated from dairy cow milk samples submitted for bacterial culture: 8,905 samples (1994-2001). J. Am. Vet. Med. Assoc. 222:1582-1589. https://doi.org/10.2460/javma.2003.222.1582.

McDougall, S. 1998. Efficacy of two antibiotic treatments in curing clinical and subclinical mastitis in lactating dairy cows. N. Z. Vet. J. 46:226-232. https://doi.org/10.1080/00480169.1998.36094.

McDougall, S. 2003. Intramammary treatment of clinical mastitis of dairy cows with a combination of lincomycin and neomycin, or penicillin and dihydrostreptomycin. N. Z. Vet. J. 51:111-116. https://doi.org/10.1080/00480169.2003.36349.

McDougall, S., K. Agnew, R. Cursons, X. Hou, and C. Compton. 2007a. Parenteral treatment of clinical mastitis with tylosin base or penethamate hydriodide in dairy cattle. J. Dairy Sci. 90:779789. https://doi.org/10.3168/jds.S0022-0302(07)71562-X.

McDougall, S., D. Arthur, M. Bryan, J. Vermunt, and A. Weir. 2007b. Clinical and bacteriological response to treatment of clinical mastitis with one of three intramammary antibiotics. N. Z. Vet. J. 55:161-170. https://doi.org/10.1080/00480169.2007.36762.

McDougall, S., L. Clausen, J. Hintukainen, and J. Hunnam. 2019. Randomized, controlled, superiority study of extended duration of therapy with an intramammary antibiotic for treatment of clinical mastitis. J. Dairy Sci. 102:4376-4386. https://doi.org/10.3168/jds .2018-15141.

McDougall, S., H. Hussein, and K. Petrovski. 2014. Antimicrobial resistance in Staphylococcus aureus, Streptococcus uberis, and Streptococcus dysgalactiae from dairy cows with mastitis. N. Z. Vet. J. 62:68-76. https://doi.org/10.1080/00480169.2013.843135.

McDougall, S., J. Niethammer, and E. Graham. 2018. Antimicrobial usage and risk of retreatment for mild to moderate clinical mastitis cases on dairy farms following on-farm bacterial culture and selective therapy. N. Z. Vet. J. 66:98-107. https://doi.org/10.1080/ 00480169.2017.1416692.

Melchior, M. B., H. Vaarkamp, and J. Fink-Gremmels. 2006. Biofilms: A role in recurrent mastitis infections? Vet. J. 171:398-407. https: //doi.org/10.1016/j.tvjl.2005.01.006.

Murray, P. R. 2010. Matrix-assisted laser desorption ionization timeof-flight mass spectrometry: usefulness for taxonomy and epidemiology. Clin. Microbiol. Infect. 16:1626-1630. https://doi.org/10 .1111/j.1469-0691.2010.03364.x.

Nobrega, D. B., J. De Buck, and H. W. Barkema. 2018a. Antimicrobial resistance in non-aureus staphylococci isolated from milk is associated with systemic but not intramammary administration of antimicrobials in dairy cattle. J. Dairy Sci. 101:7425-7436. https:/ /doi.org/10.3168/jds.2018-14540.

Nobrega, D. B., S. Naushad, S. A. Naqvi, L. A. Condas, V. Saini, J. P. Kastelic, C. Luby, J. De Buck, and H. W. Barkema. 2018b. Prevalence and genetic basis of antimicrobial resistance in nonaureus staphylococci isolated from Canadian dairy herds. Front. Microbiol. 9:256. https://doi.org/10.3389/fmicb.2018.00256.

Olde Riekerink, R. G. M., H. W. Barkema, D. F. Kelton, and D. T. Scholl. 2008. Incidence rate of clinical mastitis on Canadian dairy farms. J. Dairy Sci. 91:1366-1377. https://doi.org/10.3168/ jds.2007-0757.

Oliver, S. P., S. E. Murinda, and B. M. Jayarao. 2011. Impact of antibiotic use in adult dairy cows on antimicrobial resistance of veterinary and human pathogens: A comprehensive review. Foodborne Pathog. Dis. 8:337-355. https://doi.org/10.1089/fpd.2010.0730.

Ospina, P. A., D. Nydam, and T. DiCiccio. 2012. The risk ratio, an alternative to the odds ratio for estimating the association between multiple risk factors and a dichotomous outcome. J. Dairy Sci. 95:2576-2584. https://doi.org/10.3168/jds.2011-4515.

Petrovski, K. R., C. Heuer, T. J. Parkinson, and N. B. Williamson. 2009. The incidence and aetiology of clinical bovine mastitis on 14 farms in Northland, New Zealand. N. Z. Vet. J. 57:109-115. https: //doi.org/10.1080/00480169.2009.36887.

Petrovski, K. R., R. A. Laven, and N. Lopez-Villalobos. 2011. A descriptive analysis of the antimicrobial susceptibility of mastitiscausing bacteria isolated from samples submitted to commercial diagnostic laboratories in New Zealand (2003-2006). N. Z. Vet. J. 59:59-66. https://doi.org/10.1080/00480169.2011.552853.

Pinzón-Sánchez, C., V. Cabrera, and P. Ruegg. 2011. Decision tree analysis of treatment strategies for mild and moderate cases of clinical mastitis occurring in early lactation. J. Dairy Sci. 94:18731892. https://doi.org/10.3168/jds.2010-3930.

Pol, M., and P. L. Ruegg. 2007. Relationship between antimicrobial drug usage and antimicrobial susceptibility of gram-positive mastitis pathogens. J. Dairy Sci. 90:262-273. https://doi.org/10.3168/ jds.S0022-0302(07)72627-9.

Rollin, E., K. Dhuyvetter, and M. Overton. 2015. The cost of clinical mastitis in the first 30 days of lactation: An economic modeling tool. Prev. Vet. Med. 122:257-264. https://doi.org/10.1016/j .prevetmed.2015.11.006.

Rowe, S. M., S. Godden, E. Royster, J. Timmerman, and M. Boyle. 2021. Postcalving udder health and productivity in cows approaching dry-off with intramammary infections caused by non-aureus Staphylococcus, Aerococcus, Enterococcus, Lactococcus, and Streptococcus species. J. Dairy Sci. 104:6061-6079. https://doi.org/10 .3168/jds.2020-19288.

Rowe, S. M., S. Godden, E. Royster, J. Timmerman, B. Crooker, and M. Boyle. 2019. Cross-sectional study of the relationships among bedding materials, bedding bacteria counts, and intramammary infection in late-lactation dairy cows. J. Dairy Sci. 102:1138411400. https://doi.org/10.3168/jds.2019-17074.

Ruegg, P. L. 2017. A 100-Year Review: Mastitis detection, management, and prevention. J. Dairy Sci. 100:10381-10397. https://doi .org/10.3168/jds.2017-13023.

Runciman, D. J., J. Malmo, and M. Deighton. 2010. The use of an internal teat sealant in combination with cloxacillin dry cow therapy for the prevention of clinical and subclinical mastitis in seasonal calving dairy cows. J. Dairy Sci. 93:4582-4591. https://doi.org/10 $.3168 /$ jds.2009-2956.

Saini, V., J. T. McClure, D. Scholl, T. DeVries, and H. Barkema. 2012. Herd-level association between antimicrobial use and antimicrobial resistance in bovine mastitis Staphylococcus aureus isolates on Canadian dairy farms. J. Dairy Sci. 95:1921-1929. https://doi.org/10 $.3168 /$ jds.2011-5065.

Sargeant, J. M., A. M. O'Connor, I. Dohoo, H. Erb, M. Cevallos, M. Egger, A. K. Ersbøll, S. Martin, L. R. Nielsen, D. Pearl, D. U. Pfeiffer, J. Sanchez, M. E. Torrence, H. Vigre, C. Waldner, and M. P. Ward. 2016. Methods and processes of developing the strengthening the reporting of observational studies in epidemiology-veterinary (STROBE-Vet) statement. J. Vet. Intern. Med. 30:1887-1895. https://doi.org/10.1111/jvim.14574.

Schukken, Y. H., J. Smit, F. Grommers, D. Vandegeer, and A. Brand. 1989. Effect of freezing on bacteriologic culturing of mastitis milk samples. J. Dairy Sci. 72:1900-1906. https://doi.org/10.3168/jds .S0022-0302(89)79309-7.

Shum, L. W., C. S. McConnel, A. A. Gunn, and J. K. House. 2009. Environmental mastitis in intensive high-producing dairy herds in New South Wales. Aust. Vet. J. 87:469-475. https://doi.org/10 .1111/j.1751-0813.2009.00523.x.

Supré, K., K. Lommelen, and L. De Meulemeester. 2014. Antimicrobial susceptibility and distribution of inhibition zone diameters of bovine mastitis pathogens in Flanders, Belgium. Vet. Microbiol. 171:374-381. https://doi.org/10.1016/j.vetmic.2014.02.045.

Taylor, L. 2021. Supplemental files: Dyson et al A Survey of Mastitis Pathogens including antimicrobial susceptibility in South Eastern Australian Dairy herds. Accessed Aug. 27, 2021. osf.io/dfq7p.

Tkalcic, S., C. A. Brown, B. G. Harmon, A. V. Jain, E. P. Mueller, A. Parks, K. L. Jacobsen, S. A. Martin, T. Zhao, and M. P. Doyle. 2000. Effects of diet on rumen proliferation and fecal shedding of Escherichia coli O157:H7 in calves. J. Food Prot. 63:1630-1636. https://doi.org/10.4315/0362-028X-63.12.1630. 
Truchetti, G., É. Bouchard, L. DesCôteaux, D. Scholl, and J.-P. Roy. 2014. Efficacy of extended intramammary ceftiofur therapy against mild to moderate clinical mastitis in Holstein dairy cows: A randomized clinical trial. Can. J. Vet. Res. 78:31-37.

Vangroenweghe, F., L. Duchateau, and C. Burvenich. 2004. Moderate inflammatory reaction during experimental Escherichia coli mastitis in primiparous cows. J. Dairy Sci. 87:886-895. https://doi.org/ 10.3168/jds.S0022-0302(04)73233-6.

Watson, D. L., M. McColl, and H. Davies. 1996. Field trial of a staphylococcal mastitis vaccine in dairy herds: clinical, subclinical and microbiological assessments. Aust. Vet. J. 74:447-450. https://doi .org/10.1111/j.1751-0813.1996.tb07567.x.

Watts, J. L., T. Shryock, M. Apley, S. D. Brown, J. T. Gray, H. Heine, R. P. Hunter, D. J. Mevius, M. Paich, and P. Silley. 2008. Performance standards for antimicrobial disk and dilution susceptibility tests for bacteria isolated from animals; Approved standard-Third edition. Clinical and Laboratory Standards Institute (CLSI).

WHO-OIE. 2016. The OIE strategy on antimicrobial resistance and the prudent use of antimicrobials. World Organization for Animal
Health Paris, France, Accessed Sep. 17, 2021. https://www.oie.int/ app/uploads/2021/03/en-oie-amrstrategy.pdf

Worthing, K. A., S. Abraham, S. Pang, G. W. Coombs, S. Saputra, D. Jordan, H. S. Wong, R. J. Abraham, D. J. Trott, and J. M. Norris. 2018. Molecular characterization of methicillin-resistant Staphylococcus aureus isolated from Australian animals and veterinarians. Microb. Drug Resist. 24:203-212. https://doi.org/10.1089/ mdr.2017.0032.

\section{ORCIDS}

R. Dyson ㄴ) https://orcid.org/0000-0002-7537-2699

N. Charman $\odot$ https://orcid.org/0000-0001-8607-8789

A. Hodge 누 https://orcid.org/0000-0002-1584-5589

S. M. Rowe (1) https://orcid.org/0000-0001-8336-6523

L. F. Taylor @ https://orcid.org/0000-0002-6065-7202 